Renata Jasnos*

ORCID: 0000-0002-4954-3634

Krakow, Poland

\title{
Subjective Biblical Discourse as the Basis of Education for Relationships. \\ Discursive Interpretation Supplementing the Theological Synthesis
}

\author{
Podmiotowe dyskursy biblijne \\ jako podstawa edukacji dla relacji. \\ Interpretacja dyskursywna dopelniająca \\ syntezy teologiczne
}

Summary: The Bible is a collection of texts, which in the tradition of the Church is read as an expression of divine pedagogy or the art of God's educational influence on humankind. Developed moral principles that refer to the Bible were of a synthetic nature. Contemporary research manifests the underestimated, discursive dimension of the biblical text, which calls for a new approach to the interpretation of the biblical message. A specific process in the formation of the written biblical tradition had an impact on the discursive nature of biblical texts. Indeed, discursive analysis and interpretation is a response to the discursive nature of said texts. Bibli-

* Dr hab. Renata Jasnos, professor of Jesuit University Ignatianum in Cracow, in the Institute of Educational Sciences in the Faculty of Pedagogy. Address: Akademia Ignatianum w Krakowie, Instytut Nauk o Wychowaniu, ul. Kopernika 26, 31-501 Kraków, Poland; email: renata.jasnos@ignatianum.edu.pl 
cal discourse is often inscribed in biblical narratives. Among them, the key discourse is the subjective discourse, whose discursive partner is God himself (Jesus). They touch upon timeless problems and play an important educational role. Subjective discourse in the Bible constitutes a didactic tool for education for relationships. The article contains a brief description of selected types of subjective discourse explored from the educational perspective.

Keywords: biblical discourse; subjective discourse; discursive analysis; education for relationships.

Streszczenie: Biblia stanowi zbiór tekstów, które w tradycji Kościoła odczytywane są jako wyraz Bożej pedagogii lub sztuki wychowawczego oddziaływania Boga na człowieka. Rozwijane zasady moralne, odwołujące się do Biblii, miały charakter syntez. Tymczasem współczesne badania tekstu biblijnego wskazują na jego inny, niedoceniony wymiar - dyskursywny, który wymaga nowego podejścia do interpretacji biblijnego przesłania. Specyficzny proces formowania pisemnej tradycji biblijnej miał wpływ na dyskursywny charakter tekstów biblijnych. Dyskursywna analiza i interpretacja jest odpowiedzią na dyskursywny charakter tekstu. Biblijne dyskursy często wpisane są w narrację. Wśród nich kluczowe są podmiotowe dyskursy, których stroną (dyskursywnym partnerem) jest sam Bóg (Jezus). Poruszają one ponadczasowe problemy i pełnią ważną rolę edukacyjną. Dyskursy podmiotowe w Biblii stanowią środek dydaktyczny w edukacji do relacji. Artykuł zawiera krótką charakterystykę wybranych dyskursów podmiotowych ujętych w perspektywie edukacyjnej.

Słowa kluczowe: biblijny dyskurs; dyskurs podmiotowy; analiza dyskursywna; edukacja dla relacji.

From the beginning, the Bible was treated as a book containing principles and moral instruction. This is not surprising, because in large part it consists of legal traditions that set the rules of conduct, as well as the instructions and calls of the wise men and prophets - teachers of Israel ${ }^{1}$. From the beginning of Christianity, this way of thinking about the Bible was also

${ }^{1}$ Cf. Jerzy Bagrowicz, Jankowski Stanisław, "Pan, Bóg twój, wychowuje ciebie" (Pwt 8, 5). Studia z pedagogii biblijnej (Toruń: Wydawnictwo Naukowe Uniwersytetu Mikołaja Kopernika, 2005). 
sustained. Gregory of Nyssa, one of the fathers of the Church, called the Bible the Christian paideia $^{2}$. What is more, a contemporary scholar, André Lemaire, put forward the theory that many biblical texts came into existence in response to didactic needs ${ }^{3}$.

The moral principles and rules of conduct that formed and deepened within the framework of Church Tradition were founded on biblical traditions, developing them, or only referring to them. Their character was synthetic, and conclusive. They correspond to the nature of contemporary Catholic theology, including biblical theology.

However, contemporary research on the biblical texts points to one more of its dimensions: the rhetorical and discursive one, so far insufficiently explored. It demands a new approach to the interpretation of the biblical message ${ }^{4}$. This approach has a new potential: it permits revealing and extracting ancient educational discourses.

The present paper aims to analyse selected types of discourse as the basis of biblical education for relationships. It begins with a presentation of characteristics of the biblical texts which justify the relevance of such discursive analysis and interpretation. Discursive features result from a specific and long process of the shaping of the biblical texts.

\section{Interpretations of the biblical text - what are the foundations of discursive analysis?}

This discursiveness of biblical texts stems, on the one hand, from the adopted literary form and from the rhetorical way of constructing the message. On the other hand, it results from the specific overlapping of interpretations in the process of developing the tradition and the written message. This process involved the work of many generations of writers who developed the text as a literary composition and also a biblical tradition.

${ }^{2}$ Werner Jaeger, Wczesne chrześcijaństwo i grecka paideia (Bydgoszcz: Homini, 2002), $101-102$.

${ }^{3}$ André Lemaire, Les Écoles et la formation de la Bible dans l'ancien Israël (Fribourg: Editions Universitaires and Goettingen: Vandenhoeck and Ruprecht, 1981), 49-54.

${ }^{4}$ Renata Jasnos, "The consequences of early literacy for the discursive transmission in the Old Testament", Dialogue and Universalism 1/23 (2013): 101; cf. Renata Jasnos, "Moral Dilemmas in Biblical Literature as an Example of Educational Discourse (Chapter Nine)", in: Moral Upbringing through the Arts and Literature, eds. Paweł Kaźmierczak, Jolanta Rzegocka (Cambridge: Cambridge Scholars Publishing, 2018), 111-126. 
It is very important that writers did not obliterate the previous interpretations. While including new elements, they did not reject previous ones but tried to merge them with new insights. Therefore, the text reveals "internal development" and discursive tension. It is a witness to the development and growth of the tradition through dispute and discourse ${ }^{5}$.

It can be noted that the biblical texts (especially in the case of the Old Testament books) are 'condensed', and that different interpretations are contained within them. This in turn results from a long process of shaping the tradition and the writer's message itself, as well as from the reinterpretation and re-reading carried out in the course of work by several generations of writers $^{6}$.

It should be noted that in addition to the discursiveness of the text at the level of overlapping and combining different concepts and interpretations, there is also a discourse which the biblical text uses as a form of message transmission.

Religious and other problems are addressed in the discourse, in the dispute between heroes, or even in the rhetorical dialogue with the reader. There are numerous examples, such as the dialogues and disputes between sages and prophets, e.g. Job's polemic with "friends" (cf. Jb 4:1ff; 5:1ff; 6,1ff; 8:1ff etc.), or Amos' polemic with the leaders of the people and all the people

5 Jasnos, "The consequences", 99-100; cf. David Carr, The Formation of the Hebrew Bible. A New Reconstruction (Oxford: Oxford University Press, 2011), 13-35, 102-151; Renata Jasnos, "Kształtowanie przekazu biblijnego w kulturze wczesnej piśmienności”, in: Wiara i jej przekaz w Piśmie Świętym, ed. Roman Bogacz (Kraków: Wydawnictwo Naukowe UPJP II, 2014), 87-99; David Carr, "The Many Uses of Intertextuality in Biblical Studies. Actual and Potential”, in: Congress Volum Helsinki 2010, ed. Martti Nissinen (Helsinki: Brill, 2012), 505-535; JiSeong J. Kwon, Scribal Culture and Intertextuality Literary and Historical Relationships between Job and Deutero-Isaiah (Tuebingen: Mohr Siebeck, 2016); William Schniedewind, "Scriptualization in Ancient Judah", in: Contextualizatizing Israel's Sacred Writings. Ancient Literacy, Orality, and Literary Production, ed. Brian B. Schmidt (Atlanta: SBL Press, 2015), 305-321; Molly M. Zahn, “'Editing' and the Composition of Scripture. The Significance of the Qumran Evidence", Hebrew Bible and Ancient Israel 3 (2014): 298-316; Moshe J. Bernstein, "Rewritten Bible. A Generic Category Which Has Outlived its Usefulness?", Textus 22 (2005): 169-196; Sara Milstein, Reworking Ancient Texts: Revision through Introduction in Biblical and Mesopotamian Literature (New York: New York University, 2011) and others.

${ }^{6}$ Reinhard Mueller, Juha Pakkala, Bas ter Haar Romney, Evidence of Editing Growth and Change of Texts inthe Hebrew Bible (Atlanta: SBL Press, 2014); Carr, The Formation; Renata Jasnos, "Starotestamentalny tekst jako dydaktyczne dyskursy tożsamości w kontekście wielokulturowym", in: Edukacja międzykulturowa w warunkach kultury globalnej: Od rozważań definicyjnych do praktycznych zastosowań. Edukacja XXI wieku 30, eds. Natalia Majchrzak, Andrzej Zduniak (Poznań: Wydawnictwo Wyższej Szkoły Bezpieczeństwa, 2013), 195-206. 
(Am 2:6-3:15; 4:1-5), or Jeremiah's polemic with his countrymen (Jr 10: 1-16; and many others) and, in the New Testament, Jesus' discussions with the Scribes and Pharisees (e.g. Mt 8:18-20; 12:38-42; 15:1-9; 17:9-12; $21: 12-16 ; 21: 23-46 ; 23: 1-33 ;$ Mk 3:1-6. 22-30 and many others), and disputes between Paul and the Corinthians (cf. 1 Co $5: 1-13 ; 6: 1-7 ; 12: 1-31$; 15:1-34; 15:35-53; etc.) and other believers.

This very nature of the message requires another kind of analysis and different commentary, not a theological, "static" interpretation, and not a summary or condensed, extracted synthesis.

A more appropriate analysis is the one which raises questions about how through dialogue, disputation or description, 'specific identities, practices, knowledge and meanings are generated' 7 . The appropriate analysis is discursive, as it reveals and brings into focus the ancient discourse contained in the biblical texts.

Discursive analysis leads to the exposure and even revival of the old discourse. And revived discourse is becoming a new instrument of educational influence.

\section{Types of biblical discourse}

Considering the ambiguity of the concept of 'discourse" , and also because of the specific subject of analysis which a biblical text represents, but above all due to the research methodology, it should be indicated which understanding of the discourse will be discussed.

The concept of 'discourse' is applied to the biblical text (1) when the content is transmitted using elements of polemics with the target/default recipient, and (2) when the presented content/truth is subject to criticism, verification, and authentication, e.g. by presenting arguments, confrontation, comparison, or a seeming denial ${ }^{9}$.

7 Tim Rapley, Analiza konwersacji, dyskursu i dokumentów, trans. Anna Gąsior-Niemiec (Warszawa: PWN, 2010), 227.

${ }^{8}$ Cf. Maciej Czerwiński, "Semiotyczna analiza dyskursu”, in: Jak analizować dyskurs. Perspektywy analityczne, eds. Waldemar Czachur, Agnieszka Kulczyńska, Łukasz Kumięga (Kraków: Universitas, 2016), 41-42; Anna Duszak, Tekst, dyskurs, komunikacja międzykulturowa (Warszawa: PWN, 1998), 63-63; Aleksandra Synowiec, "W stronę analizy tekstu wprowadzenie do teorii dyskursu", Zeszyty Naukowe Politechniki Ślaskiej 65 (2013): 383-384.

${ }^{9}$ Cf. Jasnos, "Starotestamentalny", 197. 
In this paper I deal with the first type of discourse, with the discourse expressed directly. This kind of discourse can be divided further into two categories. One of them comprises (I) rhetorical texts, in which a particular speaker addresses a particular recipient/addressee in order to influence them. Many such examples may be indicated: the speeches of Moses (Dt), prophetic speeches (Is, Jr, Am, Ho etc.), and kerygmatic speeches of Saint Paul and others (Acts of the Apostles).

From the point of view of the didactic process, the more interesting type of discourse is the second one (II), i.e. discourse that is inscribed in biblical narratives. It is not a coincidence that biblical truths and messages are often expressed in the narrative, in the story. There is a separate area/field of research and interpretation of biblical texts, called narrative theology, which already has a well-established position ${ }^{10}$.

\section{Discourse inscribed in the narrative: discourse partners}

In biblical discourse expressed through narrative, the dominant kinds are those in which a broadly-understood encounter with God takes place. In the Old Testament this is Yahweh, or Elohim, and in the New Testament, Jesus Christ. These are kinds of discourse that can be called subjective.

On the other hand, a person is standing "face to face with God". In the role of the discursive "partner" of God, however, there are special characters. They combine realistic and typic features. They are described realistically, assigned to their time and place (Job lives in the land of Uz, near Petra; and the woman has just been caught in adultery), but also have typical features. These characters exhibit the features connected with the chosen existential problem of humankind. Such figures are, for example, Job (from the book of Job), Jonah (from the book of Jonah), the rich "young man" from the Gospel of Mark, the adulterous woman from the Gospel of John. Job is a righteous follower of God, subjected to great suffering. Jonah is an enraged prophet, sent by God with a mission of mercy to the enemies of his nation (Assyr-

${ }^{10}$ David M. Gunn, Danna Nolan Fewell, Narrative in the Hebrew Bible (Oxford: Oxford University Press, 1993); Narratology Hermeneutics and Midrash Jewish Christian and Muslim Narratives from Late Antiquity Through to Modern Times, eds. Constnza Cordoni, Gerhard Langer (Vienna: Vienna University Press, 2014); Francois Tolmie, Narratology and Biblical Narratives (Eugene, Oregon: Wipf \& Stock Pub, 2012) and many others. 
ians, inhabiting Nineveh - the capital of Assyria) ${ }^{11}$. The rich "young man" is a wealthy and righteous follower of God, expecting Jesus to confirm his justice (cf. Mark 10:17-22). The adulteress from the Gospel of John (cf. John $8: 1-11$ ) is a despised and condemned woman, not expecting anything, and waiting for stoning (see Table 1).

Table 1. A discursive partner of God: selected features

\begin{tabular}{|l|l|l|l|}
\hline & Realistic features & Typical features & $\begin{array}{l}\text { Represented existential } \\
\text { problem }\end{array}$ \\
\hline Job (Jb) & $\begin{array}{l}\text { lives in the land } \\
\text { of Uz [near Petra]: } \\
\text { Jb 1:1 }\end{array}$ & $\begin{array}{l}\text { righteous, right, } \\
\text { honest and rich }\end{array}$ & $\begin{array}{l}\text { innocent suffering, } \\
\text { subjected to a dramatic } \\
\text { test }\end{array}$ \\
\hline Jonah (Jon) & $\begin{array}{l}\text { son of Amittai, } \\
\text { Hebrew, worshiper } \\
\text { of Yahweh: } \\
\text { Jon 1:1.9 }\end{array}$ & $\begin{array}{l}\text { a prophet seeking } \\
\text { vengeance on the } \\
\text { enemies of Israel: } \\
\text { Jon 3:10-4:2 }\end{array}$ & $\begin{array}{l}\text { nationalism, } \\
\text { particularism; divine } \\
\text { "injustice" of mercy } \\
\text { for the enemies of the } \\
\text { "the chosen people" }\end{array}$ \\
\hline $\begin{array}{l}\text { the rich } \\
\text { "young man": }\end{array}$ & $\begin{array}{l}\text { a man who stops } \\
\text { Jesus on the way } \\
\text { (near Jericho): } \\
\text { Mk 10:17 }\end{array}$ & $\begin{array}{l}\text { observing the } \\
\text { Torah, just and rich: } \\
\text { Mk 10:19-20 }\end{array}$ & $\begin{array}{l}\text { wealth - as God's } \\
\text { reward or perhaps } \\
\text { an obstacle in the } \\
\text { relationship with God? }\end{array}$ \\
\hline $\begin{array}{l}\text { adulteress: } \\
\text { John 8:1-11 }\end{array}$ & $\begin{array}{l}\text { "A woman caught } \\
\text { in adultery": Jn 8:3 }\end{array}$ & $\begin{array}{l}\text { adulteress, despised, } \\
\text { condemned }\end{array}$ & $\begin{array}{l}\text { the holiness of the } \\
\text { people through the } \\
\text { killing of sinners or } \\
\text { their conversion; the } \\
\text { problem of the right } \\
\text { to judge others }\end{array}$ \\
\hline
\end{tabular}

A person's attitude towards the problem (the subject of discourse) is determined by knowledge, and it is expressed by the subject's emotions and actions. They are also directed towards the discourse partner. Biblical subjective discourse presented through narrative allows a dynamic presentation of the event of encounter that leaves footprints and brings with it certain consequences. It is in the narrative that the course of the event is presented: meeting, difficult dialogue, problem and discussion, dispute and even conflict.

${ }^{11}$ Cf. Waldemar Chrostowski, "Wokół historyczności Księgi Jonasza: kompozycja wyobrażona?”, Zeszyty Naukowe Stowarzyszenia Biblistów Polskich 13 (2016): 311-328. 


\section{Characteristics of subjective discourse}

The narrative shows persons who meet each other, who stand facing each other, interacting with each other. Therefore, this discourse is also distinguished by quality, expressed in the intensity and depth of the meeting, conversation, dispute and quarrel.

Such a biblical subjective discourse has its specificity. On the one hand, it is characterized by external factors: (a) direct relationship, direct conversation, direct phrases; (b) direct contact (eye contact - often meeting "face to face"); (c) physical contact, touch; (d) and the physical effects of this contact. Here are some examples of such intense contact and its consequences:

- Job: affected by leprosy by Satan, healed by God (Jb 2:7-8; 42:10);

- Jonah: hemmed in by a divine storm, swallowed by a big fish and then saved, shielded by a shady bush, and then being exposed to heat, he gave up (Jon 4.6.8);

- the rich "young man": falls to the feet of Jesus; stopping Him on the way, Jesus looked at him with love (Mk 10:21);

- the adulteress: "brought" by angry judges and executioners; freed from them by Jesus (Jn 8: 3-5. 7-9).

On the other hand, for subjective discourse the "internal" factor is crucial. The subjectivity of the described discourse is connected with the deep interaction that takes place in the interpersonal space. It is based on the intensity of the relationship and the intensity of the meeting, the latter of which is expressed through experienced emotions, that are named, expressed by word, through gesture, attitude and deeds. It is not difficult to find various examples of emotions named, expressed (in a discursive dispute) by word, gesture, by attitude and deeds. Job and his interlocutors are very expressive in showing dramatic emotions:

Then Job stood up, tore his robe and shaved his head. Then, falling to the ground, he prostrated himself and said: Naked I came from my mother's womb, naked I shall return again. Yahweh gave, Yahweh has taken back (Jb 1:20-21) ${ }^{12}$.

12 Scripture quotations (and abbreviations of the names of the biblical books) are taken in most from The New Jerusalem Bible, New York-London-Toronto: Doubleday 1985 (abbrev. NJB). 
[Job's friends] they could not recognize him; they wept aloud and tore their robes and threw dust over their heads. They sat there on the ground beside him for seven days and seven nights. To Job they spoke never a word, for they saw how much he was suffering ( $\mathrm{Jb}$ 2:12-13).

Jonah is full of grotesque anger when his enemies have converted and God shows them mercy. He is also resentful when God takes away his shady bush. He directs his anger to God:

This made Jonah very indignant; he fell into a rage (Jon 4:1)

He begged for death, saying, 'I might as well be dead as go on living.'

[God] said to Jonah, 'Are you right to be angry about the castor-oil plant?' He replied, 'I have every right to be angry, mortally angry!' (Jon 4:8-9)

The rich "young man" enters into a deep relationship first, only to sink into sadness then:

a man ran up, knelt before him [Jesus] and put this question to him, 'Good master...' (Mk 10:17).

And Jesus, looking at him, loved him,

Disheartened by the saying, he went away sorrowful (Mk 10:21-22[ESV $\left.{ }^{13}\right]$ ).

The adulterous woman is passive, she experiences her trial in silence. She says nothing, caught in sin, captured, condemned by the Pharisees, then released and justified by Jesus (Jn 8:4-5.11).

\section{Subjective discourse as a didactic means}

In addition to the external and internal factors characteristic of biblical subjective discourse (which consists of the experience of meeting, contact, with all its intensity expressed in various ways), there is another, more important characteristic. The discursive, subjective contact with God has an effect. It is more than just an experience (religious, mystical). It is the result of

${ }^{13}$ Scripture quotations are taken from The Holy Bible, English Standard Version (Wheaton, Illinois: Crossway Bibles, 2001 [abbrev. ESV]). 
reactions, movements, decisions taken as a consequence, and the broadly understood changes (changes in understanding, in behaviour, in attitudes). This often happens through a crisis that is the beginning of such a change. Job experiences the loss of property, offspring and health. He remains faithful in spite of everything, but he challenges God, and God reveals Himself to Job. This is the beginning of Job's transformation (cf. Jb 38:1; 42:1-6). Jonah is angry and outraged by the "betrayal" of God, who shows mercy to the enemies of the "chosen people". Close to death, but saved, he is called to look at his "national" enemies from the Creator's viewpoint (cf. Jon 4:11). A rich "young man", zealous and just according to the Jewish law, is experiencing a real crisis. Its expression is sadness, the cause of which is paradoxical: his own fortune, wealth (cf. Mk 10:22). The adulteress is in a critical situation: captured and condemned. She listens to angry words and demands: 'stone her to death!' But unexpectedly she experiences salvation and justification (cf. Jn 8:7-11).

Subjective discourse is characterised by the encounter of persons. The influence of the divine person is extremely strong. The prophet Amos stated that 'When the lion roars who will fear not, when the Lord God will speak, who will not prophesy?' (Am 3:8). The prophet Jeremiah complained that he could not resist God (Jr 20:9), because the power of God was overwhelming. But still, the freedom of the persons who are facing God is surprising. Although none of them can remain the same after meeting God, the dispute and discourse itself reveals the space of extraordinary freedom that God gives them.

It is the freedom of a person. For Jonah, it is the freedom to resist God. It is Job's freedom to challenge God ('But my words are intended for Shaddai; I mean to remonstrate with God'; Jb 13:3-28; cf. 16:18-21; 23:1-7; cf. $31: 35-40 ; 34: 34-37)$. The freedom of the sinful woman is both physical liberation from those who would condemn her, and also freedom from guilt ('Neither do I condemn you' Jn 8:11). It is the freedom of a rich man who, despite being called ('come, follow me'; Mk 10:21), can leave and actually does leave.

Freedom of the person, respected by God, is the basis for inner change. This freedom is an effect of treating the discourse partner with respect. This respect for human freedom is an expression of recognition and even 'elevation' (through recognition) of human dignity when it is threatened (cf. the leprous Job on a pile of manure; the condemned adulteress). This respect is also expressed in a serious treatment. God responds to the call and the challenge of Job, who is 'crushed by suffering'. He patiently continues the 
'dialogue' with the rebellious Jonah, who is offended and unresponsive, and runs away from the assigned task and from God. Jesus stops and answers the rich man's question; he looks with appreciation and love, but lets him go. He takes the sinful woman's side, exposing himself to the wrath of the Pharisees, and justifies the one whom everyone has despised.

The didactic nature of these narrative texts is expressed not only in the fact that they "tell" and describe. The most important thing is that the problem they contain is discussed. And discourse inscribed in narratives not only shows dispute, influence and change. Biblical discourse is narratively "open": the problem is not fully explained, and the characters have not made the final choice. It remains open to the reader. This rhetorical treatment indicates the didactic purpose of the text.

"Open" discourse, unfinished, can be presented in various ways. The discussion that constitutes the entire Book of Job ends surprisingly. Job withdraws and states that his experience of God has overpowered him:

You have told me about great works that I cannot understand, about marvels which are beyond me, of which I know nothing.

Before, I knew you only by hearsay but now, having seen you with my own eyes, I retract what I have said ( $\mathrm{Jb} 42: 3.5-6)$.

The book of Jonah ends with an open rhetorical question: 'You pity the plant,... And should not I pity Nineveh, that great city,....?' (Jon 4:10$-11[E S V])$. The rich "young man" leaves without saying anything, and only his sadness testifies to the crisis as a potential beginning of a possible change: 'he went away sorrowful' (Mk 10:22). The Pharisees and the "scribes" are relentless at first, ready to stone the woman, but then suddenly they go silent and unexpectedly leave. The sinful woman hears 'and I do not condemn you, go ..., do not $\sin . .$. ' (Jn 8: 9.11). The Evangelist says nothing more.

Such restraint, and lack of "follow-up", clearly shows the goal of an inspired writer, who leaves the reader with the task of completing the story with his or her own life.

\section{Conclusion - education for relationships}

Subjectivity is a distinctive feature of biblical discourse. The function of subjective discourse consists of stimulating attempts to seek answers to the problems posed. These problems are located in the interpersonal space of 
human relations (concerning mercy towards strangers, suffering before God, personal justice before God, and guilt in relation to your neighbour).

As a consequence, discourse leads to personal development. Discourse concerns education and upbringing for relationships. These discourses testify to such education in antiquity, but also to didactic purposes assigned to the text itself. This is evidenced by the open composition of the biblical discourse.

The real and difficult challenge today is a contemporary application of biblical discourse. This practice of updating belongs to the biblical tradition, and it was the basis for shaping the biblical text. Such updating of interpretations belongs to those factors that make the biblical texts still able to fulfil their didactic function. They can be used as a basis for personal reflection or group discussions. Such a discussion and interpretation of biblical discourse in confrontation with the realities of modern man's life is a further update of biblical texts. Their educational potential lies in their dialogical and discursive nature. Using these texts in education leads to the development of students' subjective relationships.

The message of the Bible being read and interpreted only in the form of synthesis leads to shaping theories. This is how studies in biblical theology come into being. To stop at the very theory is in fact a misunderstanding and denies the message and the call of the Bible. Discursive interpretation is complementary to theological synthesis.

\section{References}

Bagrowicz, Jerzy, Stanisław Jankowski. "Pan, Bóg twój, wychowuje ciebie” (Pwt 8, 5). Studia z pedagogii biblijnej. Toruń: Wydawnictwo Naukowe Uniwersytetu Mikołaja Kopernika, 2005.

Bernstein, Moshe J. "Rewritten Bible. A Generic Category Which Has Outlived its Usefulness?”. Textus 22 (2005): 169-196.

Carr, David. The Formation of the Hebrew Bible. A New Reconstruction. Oxford: Oxford University Press, 2011.

Carr, David. "The Many Uses of Intertextuality in Biblical Studies. Actual and Potential”. In: Congress Volum Helsinki 2010, ed. Martti Nissinen, 505-535. Helsinki: Brill, 2012.

Chrostowski, Waldemar. "Wokół historyczności Księgi Jonasza: kompozycja wyobrażona?”. Zeszyty Naukowe Stowarzyszenia Biblistów Polskich 13 (2016): $311-328$. 
Czerwiński, Maciej. "Semiotyczna analiza dyskursu”. In: Jak analizować dyskurs. Perspektywy analityczne, eds. Waldemar Czachur, Agnieszka Kulczyńska, Łukasz Kumięga, 41-58. Kraków: Universitas, 2016.

Duszak, Anna. Tekst, dyskurs, komunikacja międzykulturowa. Warszawa: PWN, 1998.

Grant-Henderson, Anna L. Inclusive Voices in Post-Exilic Judah. Collegeville: The Liturgical Press, 2002.

Gunn, David M., Danna Nolan Fewell. Narrative in the Hebrew Bible. Oxford: Oxford University Press, 1993.

Jaeger, Werner. Wczesne chrześcijaństwo i grecka paideia. Bydgoszcz: Homini, 2002.

Jasnos, Renata. "Dydaktyczny charakter biblijnej księgi na przykładzie Deuteronomium”. Paedagogia Christiana 2/24 (2009): 81-94.

Jasnos Renata. Deuteronomium jako „księga” w kontekście kultury piśmienniczej starożytnego Bliskiego Wschodu. Kraków: WAM - Ignatianum, 2011.

Jasnos, Renata. "Starotestamentalny tekst jako dydaktyczne dyskursy tożsamości w kontekście wielokulturowym”. In: Edukacja międzykulturowa w warunkach kultury globalnej: Od rozważań definicyjnych do praktycznych zastosowań. Edukacja XXI wieku 30, eds. Natalia Majchrzak, Andrzej Zduniak, 195-206. Poznań: Wydawnictwo Wyższej Szkoły Bezpieczeństwa, 2013.

Jasnos, Renata. "The consequences of early literacy for the discursive transmission in the Old Testament”. Dialogue and Universalism 1/23 (2013): 91-103.

Jasnos, Renata. "Kształtowanie przekazu biblijnego w kulturze wczesnej piśmienności”. In: Wiara i jej przekaz w Piśmie Świętym, ed. Roman Bogacz, 87-99. Kraków: Wydawnictwo Naukowe UPJP II, 2014.

Jasnos, Renata. "Międzykulturowść - wzbogacenie czy zagrożenie? Starożytny dyskurs biblijny w perspektywie edukacyjnej”. In: Podmioty, środowiska i obszary edukacyjne: Wyzwania i zagrożenia połowy XXI wieku. Edukacja XXI wieku, eds. Natasza Starik, Teresa Węglarz, 251-261. Poznań: Wydawnictwo Wyższej Szkoły Bezpieczeństwa, 2015.

Jasnos, Renata. "Moral Dilemmas in Biblical Literature as an Example of Educational Discourse (Chapter Nine)". In: Moral Upbringing through the Arts and Literature, eds. Paweł Kaźmierczak, Jolanta Rzegocka, 111-126. Cambridge: Cambridge Scholars Publishing, 2018.

Knoppers, Gary N. "Rethinking the Relationship between Deuteronomy and Deuteronomistic History: The Case of Kings". The Catholic Biblical Quarterly 63 (2001): 393-415.

Kratz, Reinhard G. "Rewriting Isaiah 28-31". In: Prophecy and the Prophets in Ancient Israel, ed. John Day, 245-266. New York-London: T\&T Clark, 2010. 
Kwon, JiSeong J. Scribal Culture and Intertextuality Literary and Historical Relationships between Job and Deutero-Isaiah. Tuebingen: Mohr Siebeck, 2016.

Lemaire, André. Les Écoles et la formation de la Bible dans l'ancien Israël. Fribourg: Editions Universitaires and Goettingen: Vandenhoeck and Ruprecht, 1981.

Milstein, Sara. Reworking Ancient Texts: Revision through Introduction in Biblical and Mesopotamian Literature. New York: New York University, 2011.

Mueller, Reinhard, Juha Pakkala, Bas ter Haar Romney. Evidence of Editing Growth and Change of Texts inthe Hebrew Bible. Atlanta: SBL Press, 2014.

Narratology Hermeneutics and Midrash Jewish Christian and Muslim Narratives from Late Antiquity Through to Modern Times, eds. Constnza Cordoni, Langer Gerhard. Vienna: Vienna University Press, 2014.

Rapley, Tim. Analiza konwersacji, dyskursu i dokumentów, trans. Anna Gąsior-Niemiec. Warszawa: PWN, 2010.

Schniedewind, William. "Scriptualization in Ancient Judah". In: Contextualizatizing Israel's Sacred Writings. Ancient Literacy, Orality, and Literary Production, ed. Brian B. Schmidt, 305-321. Atlanta: SBL Press, 2015.

Smith, Anthony D. The Cultural Foundations of Nations: Hierarchy, Covenant and Republic. Oxford: Wiley - Blackwell, 2008.

Synowiec, Aleksandra. "W stronę analizy tekstu - wprowadzenie do teorii dyskursu”. Zeszyty Naukowe Politechniki Ślaskiej 65 (2013): 383-396.

Tolmie, Francois. Narratology and Biblical Narratives. Eugene, Oregon: Wipf \& Stock Pub, 2012.

Walton, John H., Victor H. Matthews, Mark W. Chavalas. Komentarz historyczno-kulturowy do Biblii Hebrajskiej, trans. Zbigniew Kościuk. Warszawa: Vocatio, 2005.

Zahn, Molly M. "'Editing' and the Composition of Scripture. The Significance of the Qumran Evidence". Hebrew Bible and Ancient Israel 3 (2014): 298-316. 